\title{
COCONUT LEAF WASTE PROCESSING WITH BIODRYING PROCESS AS RAW MATERIAL FOR BIOMASS PELLETS IN WASTE TO ENERGY
}

\author{
Nova Ulhasanah, Ariyanti Sarwono, Michael Yosafaat, Dennis Filippi, Mega Mutiara Sari, \\ I Wayan Koko Suryawan
}

Faculty of Infrastructure Planning, Department of Environmental Engineering, Universitas Pertamina, Komplek Universitas Pertamina, Jakarta, INDONESIA

E-mail: i.suryawan@universitaspertamina.ac.id

\begin{abstract}
Coconut leaf waste is a type of waste that contains a good enough calorific value to be used as raw material for biomass pellets. The minimum standard calorific value of biomass in Indonesia according to SNI 8675:2018 is $16.05 \mathrm{MJ} / \mathrm{kg}$. Meanwhile, based on the research results, the calorific value of coconut leaf waste has a value of $13.34 \mathrm{MJ} / \mathrm{kg}$. The way that can be applied to increase the calorific value is by biodrying. This study aimed to determine the effectiveness of the biodrying process in processing coconut leaf waste. This study use bioactivators in the form of tempe yeast, baker's yeast, and tapai yeast. Mass loss and moisture reduction can be achieved, respectively, 8.25$17.62 \%$ and $62.4-65.6 \%$. The calorific value can reach the minimum standard after seven days of processing with a value of $17,995-18,623 \mathrm{MJ} / \mathrm{kg}$.
\end{abstract}

Key word: biodrying; coconut leaves; waste; caloric value.

\begin{tabular}{cccc}
\hline Received: & Revised: & Accepted: & Available online: \\
2021-11-16 & $2021-11-27$ & $2021-12-16$ & $2022-01-08$ \\
\hline
\end{tabular}

\section{INTRODUCTION}

The Bali Island is known as the Island of a Thousand Temples. Prayers are carried out every day by residents using various means. Some of the leading facilities in the procession of Hindu worship in Bali. Coconut leaves used as the main ingredients for making canang, and sampian in fresh coconut leaves from the coconut plant (Cocos nucifera L.) obtained from Bali and outside Bali or coconut leaves from the coconut plant. The rest of this can produce waste, and research also shows that this waste generation made from coconut leaves is found in water bodies (Widyarsana et al., 2020). The problem of waste in water bodies is indeed a significant problem in Bali Province, especially related to marine debris (Septiariva \& Suryawan, 2021).

Waste can be appropriately managed through increasing public awareness of the environment and collaboration with various stakeholders to take advantage of opportunities for renewable energy sources through the development of technology for converting waste into energy. The waste management system has progressed and can even be used as alternative energy in waste energy generation but has not been used optimally on a large scale. Various waste utilization techniques can be applied to convert waste into energy, namely, thermal conversion technology and biological mechanisms. Waste energy conversion in the form of thermal with a pyrolysis system has been carried out in several areas in Indonesia, including the Province of Bali (Qonitan et al., 2021). However, this process requires quality fuel with low moisture content and high calorific value.

Coconut leaf waste tends to have reasonably high water content and has a high calorific value potential, so proper processing is needed to remove the water content (Pestaño \& Jose, 2016). One of the processing that can be done is the biodrying process (Suryawan et al., 2021). The biodrying process takes a long time, so that in its application, a biocatalyst is needed to remove water. The biological catalysts that can be used are fungi. Some of the fungi that can be found in the Indonesian market are tempe yeast, baker's yeast, and tepai yeast. This study aimed to determine the effectiveness of processing coconut leaf waste with the addition of yeast bio activator on coconut leaf waste to obtain the optimum calorific value. 


\section{RESEARCH METHODS \\ Materials}

The volume rector that used in this study is 2 litres in size, where the reactor used is closed. The air supply is carried out using an aerator with a flow rate of $\pm 2 \mathrm{~L} / \mathrm{min}$ each. The reactor is equipped with a sampling port to analyze the humidity and $\mathrm{pH}$ of the waste every day. At the bottom, it is fitted with a bulkhead containing perforated baffles to collect leachate (Figure 1). Moisture and $\mathrm{pH}$ measurements were carried out with a moisture meter and a $\mathrm{pH}$ meter. The coconut leaf waste used is fresh waste produced at that time. The mass of the waste is measured using a digital scale. Before weighing the leachate chamber, it is ensured that there is no water remaining. The waste mass is the measurement when considered minus the mass of the reactor.

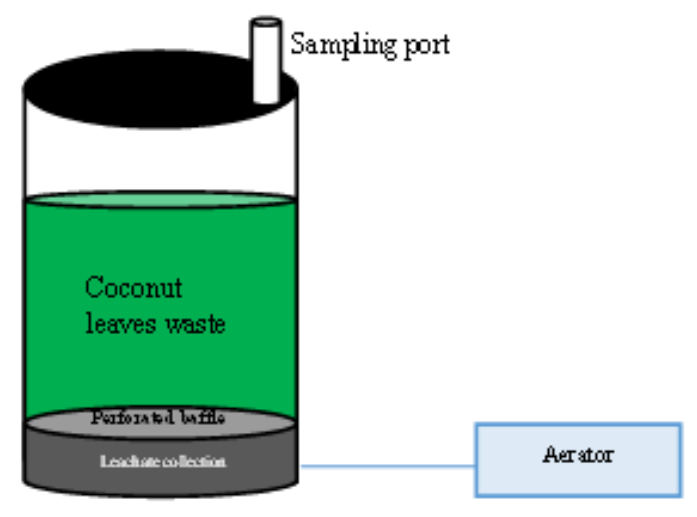

Figure 1. Biodrying Reactor used in Coconut Leaf Waste Treatment

\section{Methods}

This research was conducted in the Bekasi area, West Java, in October - November 2020. Samples of coconut leaves were obtained from nearby markets. The calorific value test was carried out in the laboratory of the Animal Research Institute (Balitnak), Bogor, West Java. Moisture measurement is carried out with a moisture meter adjusted. Meanwhile, $\mathrm{pH}$ measurement is also carried out with a $\mathrm{pH}$ meter that is adjusted. The measurement of $\mathrm{pH}$ and moisture is carried out every day, including temperature. Temperature is measured with a thermometer. Calorific value measurements were carried out at the beginning and end of the study. Measurement of calorific value using bomb calorimetry with standard SNI 01-6325-2000. The detention time used in this study was seven days and an increase in the airflow rate of $2 \mathrm{~L} /$ minute based on previous research by (Fadlilah \& Yudihanto, 2013).

\section{Data Analysis}

Data analysis was carried out by descriptive method on changes in moisture value, water content, temperature and $\mathrm{pH}$. The calorific value results are compared with the criteria set in Indonesia. In addition, data analysis is also supported by literature studies related to this research.

\section{RESULT AND DISCUSSION}

The results of the measurement of the initial characteristics of coconut leaf waste can be seen in Table 1. The measurement results show the moisture content value of 31.4-36.1\%, while the known calorific value is $13.34 \mathrm{MJ} / \mathrm{kg}$. Meanwhile, other parameters that support the growth of microorganisms in the biodrying process are lignin, cellulose, Nitrogen, Carbon-organic (Corganic), and Phospate are $20.55 \% ; 37.56 \%, 2.26 \%, 30.05 \%$, and $0.42 \%$, respectively.

The biodrying process focuses on aerobic technology, which reduces the moisture content to steam due to high temperatures and adequate ventilation. Bioderying process showed that proper aeration settings (e.g., discharge and flow direction) and temperature are able to reduce water content 
efficiently (Adani et al., 2002; Sugni et al., 2005). However, the principle of aerobic biodrying technology is to promote evaporation using the energy generated by the degradation of organic matter. The amount of organic carbon contained in the raw material of coconut leaf waste is $30.05 \%$, and cellulose is $37.56 \%$. The addition of aeration in the biodrying process can increase the partial disintegration and hydrolysis of macromolecular organic compounds such as C-Organic, cellulose, hemicellulose, lignin, total nitrogen (Nguyen et al., 2007). The cellulose content in coconut leaf waste causes the decomposition process of this waste to take a very long time to do.

Table 1. Results of Measurement of Initial Characteristics of Coconut Leaf Waste

\begin{tabular}{lc}
\hline Parameters & $\begin{array}{c}\text { Waste Initial } \\
\text { Characteristic }\end{array}$ \\
\hline Moisture (\%) & $31.4-36.1$ \\
Ash (\%) & 8.36 \\
Caloric Value (MJ/kg) & 13.34 \\
Lignin (\%) & 20.55 \\
Cellulose (\%) & 37.56 \\
N (\%) & 2.26 \\
C-Organic (\%) & 30.05 \\
C/N Ratio & 13.3 \\
P (\%) & 0.42 \\
\hline
\end{tabular}

Changes in moisture and mass can be seen in Figure 2. It can be seen that each variation of the addition of bread has almost the same trend, where the largest decrease in mass occurs on the first day. Changes in mass tend to start steady after the first day. Meanwhile, moisture began to decrease on the fifth day.

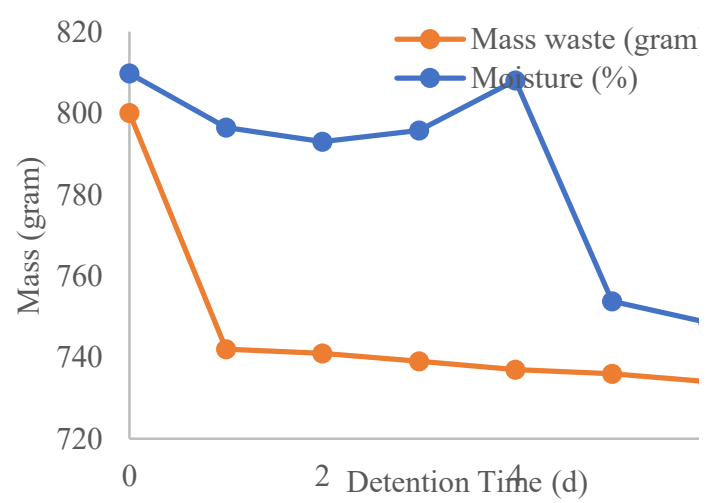

a. Changes in Mass and Moisture in Biodrying with Tempeh Yeast Bioactivator

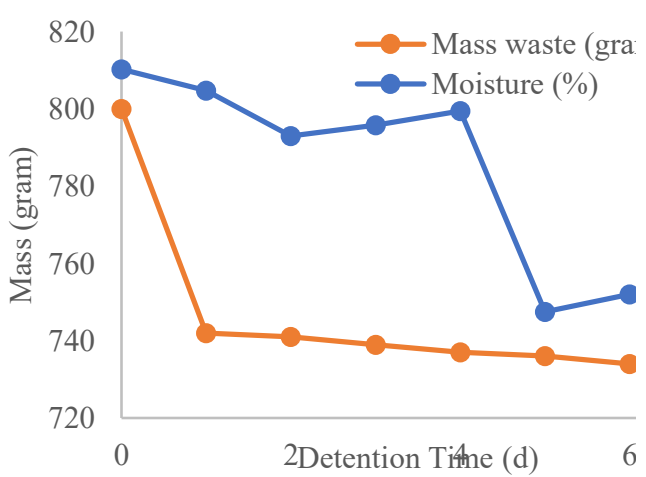

b. Changes in Mass and Moisture in Biodrying with Bread Yeast Bioactivator 


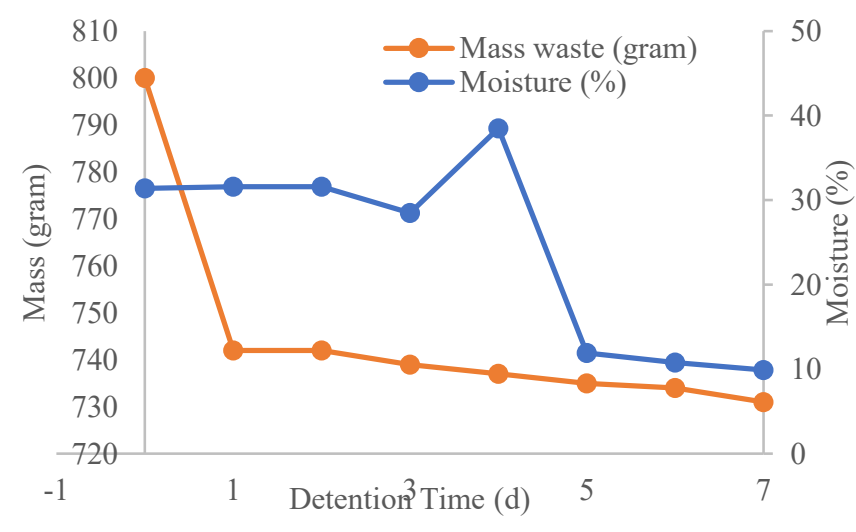

c. Changes in Mass and Moisture in Biodrying with Tapai Yeast Bioactivator

Figure 2. Changes in Moisture Trends and Waste Mass During the Biodrying Process with Tempe Yeast (a) Bread Yeast (b) and Tapai Yeast (c)

Figure 3 shows the trend of changes in $\mathrm{pH}$ and temperature during the biodrying process. The $\mathrm{pH}$ in the processing does not change during the process, which shows that the $\mathrm{pH}$ value is still in a normal $\mathrm{pH}$ condition of 7. At the same time, the temperature in each bioactivator has a different value. The trend for tempe yeast and tepai yeast tends to be the same. The percentage of weight loss in the tempe yeast variation was higher, while the reduction was almost the same (Figure 4).

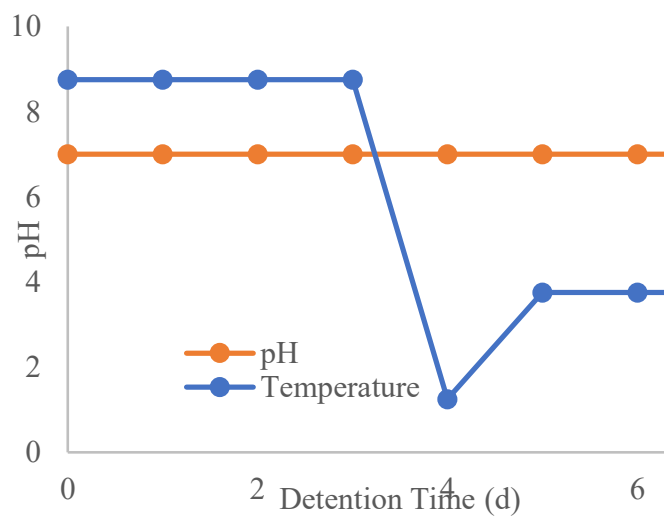

a. Changes in $\mathrm{pH}$ and temperature in Biodrying with Tempeh Yeast Bioactivator

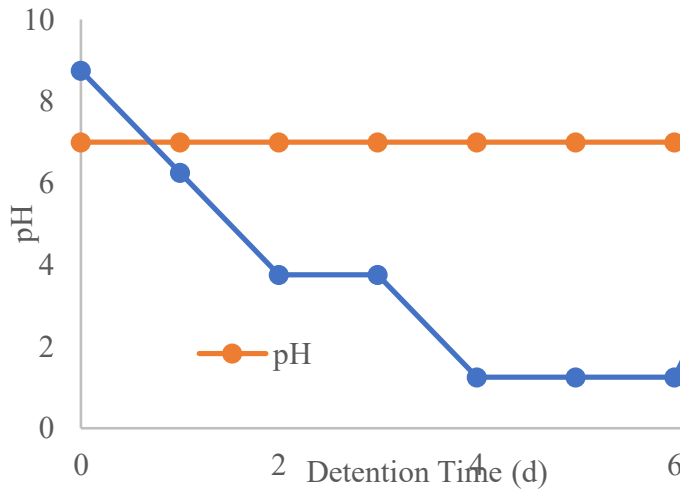

b. Changes in $\mathrm{pH}$ and temperature in Biodrying with Bread Yeast Bioactivator

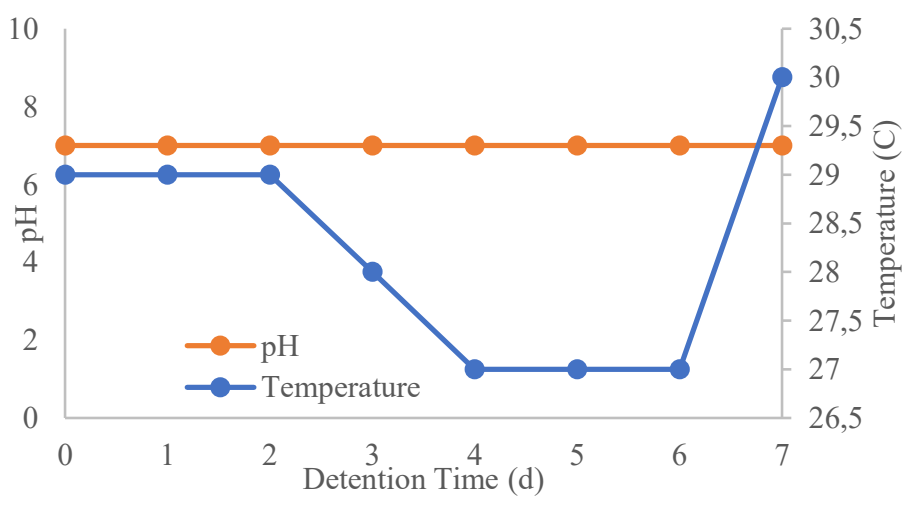

c. Changes in $\mathrm{pH}$ and temperature in Biodrying with Tapai Yeast Bioactivator 
Figure 3. Changes in the $\mathrm{pH}$ and Temperature Trends of Waste During the Biodrying Process with Tempe Yeast (a) Bread Yeast (b) and Tapai Yeast (c)

The temperature in the processing process tends to be high at the beginning of processing and decreases with processing time. A gradual decrease in biodrying temperature is an indication that the activity of microorganisms is going well (Debertoldi et al., 1983). The higher temperature causes the evaporation of water and extractive materials as well as the degradation of hemicellulose so that the water content decreases. Temperature affects biordying, affecting the biodying product as indicated by the value of water content, ODS (organic dry solid), carbon and ash (Fadlilah \& Yudihanto, 2013). $\mathrm{pH}$ normal during the processing indicates the occurrence of the optimum microbial process in processing coconut leaf waste. The $\mathrm{pH}$ value of 6.7-9.0 strongly supports microbial activity during the degradation process (Sofiyah \& Suryawan, 2021).

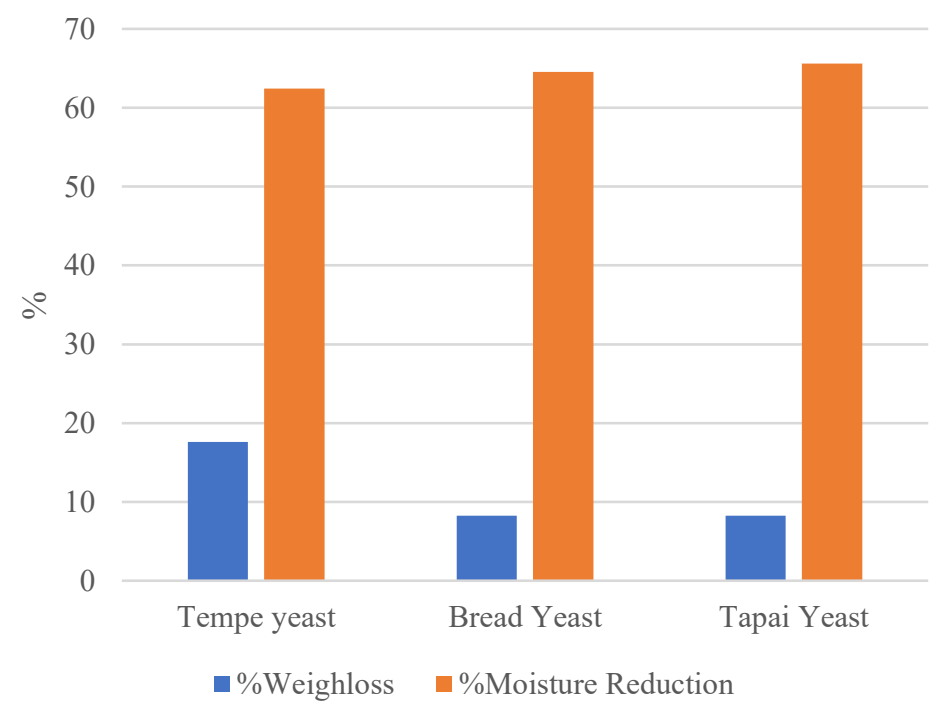

Figure 4. The Effectiveness of Weight Reduction and Moisture Reduction in the Biodrying Process for 7 days

In Table 2, it can be seen that the highest calorific value was obtained with the addition of yeast bioactivator. The increase in calorific value with the addition of bioactivator can reach 25.87 to $28.36 \%$. The processing results showed that the highest mass decrease was higher on day 2 , while the decrease in moisture content tended to occur on day 5. The amount of energy also required mainly depended on the amount of water content of the waste. If the water content of the waste is high, the energy required for drying and burning is also high (Sarwono et al., 2021). The effectiveness of the biodrying process is high-temperature differentiation, namely the necessary gradual temperature increase, stirring to accelerate heat transfer, and the size of the sample.

Table 2. Value and Change in Waste Calorific Value for Each Biodrying Process Variation

\begin{tabular}{ccc}
\hline Bioactivator & $\begin{array}{c}\text { Caloric Value } \\
(\mathrm{MJ} / \mathrm{kg})\end{array}$ & $\begin{array}{c}\text { \% Increase of Caloric } \\
\text { Value from Initial }\end{array}$ \\
\hline Tempe Yeast & 18.623 & 28.36 \\
Bread Yeast & 18.167 & 26.57 \\
Tapai Yeast & 17.995 & 25.87 \\
\hline
\end{tabular}

The percentage of mass loss in this study has differences in other studies. Other studies have shown that the mass reduction in the biodrying process can be more than $30 \%$ (Colomer-Mendoza et al., 2013; Mohammed et al., 2017). This may be because the detention time given is not long enough, whereas other studies require more than 14 days. In addition, coconut leaf waste also has a fairly 
high cellulose content compared to food waste, usually used in the biodrying process. However, 14 days is considered long enough, so 7 days is also good enough. In terms of quality, the measurement of the calorific value of the results of biodrying processing can reach $17.995-18.623 \mathrm{MJ} / \mathrm{kg}$, which increases to $25.87-28.36 \%$. Biomass pellet raw materials based on Indonesian standards must meet the minimum standard of $16.50 \mathrm{MJ} / \mathrm{kg}$ (SNI 8675:2018). This shows that the raw material for coconut leaf waste, which was previously $13.34 \mathrm{MJ} / \mathrm{kg}$, has not met the criteria applied in Indonesia. This biodrying process will provide the possibility that coconut leaf waste can be used as raw material for biomass pellets.

\section{CONCLUSION}

Loss of weight and moisture in coconut leaf waste during the biodrying process can reach 8.25$17.62 \%$ and $62.4-65.6 \%$, respectively. The increase in calorific value can also reach 25.87 to $28.36 \%$. The final calorific value in the biodrying process can reach the Indonesian minimum standard for biomass pellets, which is $17.995-18.623 \mathrm{MJ} / \mathrm{kg}$.

\section{ACKNOWLEDGEMENT}

The authors would like to thank Universitas Pertamina LPPMI assists this research with an annual community service scheme (SK No. 0197F/UP-R/SK/XII/2020). The author is also grateful to those who have helped in carrying out this service.

\section{REFERENCES}

Adani, F., Baido, D., Calcaterra, E., \& Genevini, P. (2002). The influence of biomass temperature on biostabilization-biodrying of municipal solid waste. Bioresource Technology, 83(3), 173-179. https://doi.org/10.1016/S0960-8524(01)00231-0

Colomer-Mendoza, F. J., Herrera-Prats, L., Robles-Martínez, F., Gallardo-Izquierdo, A., \& PiñaGuzmán, A. B. (2013). Effect of airflow on biodrying of gardening wastes in reactors. Journal of Environmental Sciences, 25(5), 865-872. https://doi.org/10.1016/S1001-0742(12)60123-5

Debertoldi, M., Vallini, G., \& Pera, A. (1983). The biology of composting: A review. Waste Management \& Research, 1(2), 157-176. https://doi.org/10.1016/0734-242X(83)90055-1

Fadlilah, N., \& Yudihanto, G. (2013). Pemanfaatan Sampah Makanan Menjadi Bahan Bakar Alternatif dengan Metode Biodrying. Teknik Pomits, 2(2), 289-293.

Mohammed, M., Ozbay, I., \& Durmusoglu, E. (2017). Bio-drying of green waste with high moisture content. Process Safety and Environmental Protection, 111, 420-427. https://doi.org/10.1016/j.psep.2017.08.002

Nguyen, P. H. L., Kuruparan, P., \& Visvanathan, C. (2007). Anaerobic digestion of municipal solid waste as a treatment prior to landfill. Bioresource Technology, 98(2), 380-387. https://doi.org/10.1016/J.BIORTECH.2005.12.018

Pestaño, L. D. B., \& Jose, W. I. (2016). Production of Solid Fuel by Torrefaction Using Coconut Leaves As Renewable Biomass. International Journal of Renewable Energy Development, 5(3), 187-197. https://doi.org/10.14710/ijred.5.3.187-197

Qonitan, F. D., Suryawan, I. W. K., \& Rahman, A. (2021). Overview of Municipal Solid Waste Generation and Energy Utilization Potential in Major Cities of Indonesia. Journal of Physics: Conference Series, 1858(1). https://doi.org/10.1088/1742-6596/1858/1/012064

Sarwono, A., Septiariva, I. Y., Qonitan, F. D., Zahra, N. L., Sari, N. K., Fauziah, E. N., Ummatin, K. K., Amoa, Q., Faria, N., Wei, L. J., \& Suryawan, I. W. K. (2021). Municipal Solid Waste Treatment for Energy Recovery Through Thermal Waste-To-Energy in Depok City, Indonesia. Journal of Advanced Research in Fluid Mechanics and Thermal Sciences, 85.

Septiariva, I. V. A. Y., \& Suryawan, I. W. K. (2021). Development of water quality index (WQI) and hydrogen sulfide (H2S) for assessment around suwung landfill, Bali Island. Journal of Sustainability Science and Management, 16(4), 137-148. 
Sofiyah, E. S., \& Suryawan, I. W. K. (2021). Cultivation of Spirulina platensis and Nannochloropsis oculata for nutrient removal from municipal wastewater. Rekayasa, 14(1), 93-97. https://doi.org/10.21107/rekayasa.v14i1.8882

Sugni, M., Calcaterra, E., \& Adani, F. (2005). Biostabilization-biodrying of municipal solid waste by inverting air-flow. Bioresource Technology, 96(12), 1331-1337. https://doi.org/10.1016/J.BIORTECH.2004.11.016

Suryawan, I. W. K., Wijaya, I. M. W., Sari, N. K., \& Yenis, I. (2021). Potential of Energy Municipal Solid Waste ( MSW ) to Become Refuse Derived Fuel ( RDF ) in Bali Province, Indonesia. Jurnal Bahan Alam Terbarukan, 10(200).

Widyarsana, I. M. W., Damanhuri, E., Ulhusna, N., \& Agustina, E. (2020). A Preliminary Study: Identification of Stream Waste Quantity and Composition in Bali Province, Indonesia. 5. 